\title{
PERILAKU AMAN PADA PEKERJA OPERATOR LOADING UNLOADING MINYAK MENTAH
}

\section{SAFETY BEHAVIOR OF LOADING UNLOADING CRUDE OIL OPERATOR}

\author{
Feby Cahyani \\ PT. Telkomedika \\ E-mail: febycahyani402@gmail.com
}

\begin{abstract}
Elements that play an important role in the cause of occupational accidents are human behavior. Thus reducing the occurrence of unsafe behavior is an effective way to prevent the occurrence of work accidents. From the results of preliminary studies conducted in the production area of PT X from 10 workers who observed the behavior of the use of PPE there were 3 workers who did not behave safely. This study aims to analyze the safe behavior and its causes in the effort of prevention of work accident by using Antecedence, Behaviour and Consequences (ABC) behavior model. This research used cross-sectional design. Data collection was obtained through measurement and observation. The population of this research was 20 workers loading unloading crude oil. The result of the research showed that $50 \%$ of workers doing the safe behavior. The safe behavior of the use of PPE by $80 \%$, the implementation of housekeeping by $70 \%$, and follow the Standard Operating Procedure (SOP) of $83 \%$. Safe behavior was triggered by the important role of knowledge that workers have good enough about Occupational Health and Safety (OHS) and safe behavior, worker attitudes toward safe behavior also quite good, and the training received is good enough. Besides giving rewards and punishment by the company also helped motivate workers to behave safely. While unsafe behavior that workers do not use a respirator and does not maintain the cleanliness of the workplace.
\end{abstract}

Keywords: ABC model, loading unloading operator, safe behavior

\begin{abstract}
ABSTRAK
Unsur yang memegang peran penting dalam penyebab kecelakaan kerja adalah perilaku manusia. Mengurangi terjadinya perilaku tidak aman adalah cara efektif untuk mencegah terjadinya kecelakaan kerja. Hasil studi awal yang dilakukan di area produksi PT X dari 10 pekerja yang diamati perilaku penggunaan APD terdapat 3 pekerja yang tidak berperilaku aman. Penelitian ini bertujuan untuk menganalisis perilaku aman serta penyebabnya dalam upaya pencegahan kecelakaan kerja dengan menggunakan model perilaku Antecedence Behaviour and Consequences $(A B C)$. Penelitian ini menggunakan rancang bangun cross-sectional study. Pengambilan data diperoleh melalui pengukuran dan observasi dengan menggunakan kuesioner. Populasi penelitian berjumlah 20 orang pekerja operator produksi pada PT X. Hasil penelitian menunjukkan bahwa pekerja yang melakukan perilaku aman sebesar 50\%. Perilaku aman penggunaan APD sebesar $80 \%$, pelaksanaan housekeeping sebesar 70\%, dan mengikuti Standar Operasional Prosedur (SOP) sebesar 83\%. Perilaku aman tersebut dipicu oleh peran penting dari pengetahuan yang dimiliki pekerja cukup baik mengenai Keselamatan dan Kesehatan Kerja (K3) dan perilaku aman. Sikap pekerja terhadap perilaku aman juga cukup baik, serta pelatihan yang diterima sudah cukup baik. Selain itu pemberian reward dan punishment oleh perusahaan juga turut memotivasi pekerja untuk berperilaku aman. Perilaku tidak aman yang dilakukan pekerja meliputi tindakan tidak menggunakan respirator dan tidak menjaga kebersihan tempat kerja.
\end{abstract}

Kata kunci: model perilaku $\mathrm{ABC}$, pekerja loading unloading, perilaku aman

\section{PENDAHULUAN}

Kementerian Tenaga Kerja dan Transmigrasi (Kemenakertrans) menyatakan bahwa pada tahun 2010 terdapat 98.000 kasus kecelakaan kerja dengan 1.200 orang tewas. Pada tahun 2011, angka kecelakaan kerja semakin meningkat, yaitu menjadi
99.000 kasus dan menewaskan 2.218 orang. Data Kemenakertrans juga menyebutkan bahwa sampai dengan tahun 2013 terdapat enam pekerja meninggal dunia setiap hari akibat dari kecelakaan kerja di Indonesia. 
Kecelakaan kerja yang terjadi di Indonesia masih tinggi, hingga akhir 2015 telah terjadi kecelakaan kerja sebanyak 105.182 kasus. Kasus kecelakaan dalam kategori berat yang mengakibatkan kematian tercatat sebanyak 2.375 kasus dari total jumlah kecelakaan kerja. Penyebab utama dari kecelakaan kerja tersebut adalah rendahnya kesadaran akan pentingnya penerapan Keselamatan dan Kesehatan Kerja (K3) pada kalangan industri dan masyarakat. Penerapan K3 seharusnya dianggap sebagai investasi untuk mencegah terjadinya kecelakaan kerja, namun masyarakat dan kalangan industri masih menganggapnya sebagai cost atau beban biaya (BPJS Ketenagakerjaan, 2016). Ningsih (2013) menyatakan bahwa s sebanyak $88 \%$ kecelakaan kerja disebabkan karena perilaku tidak aman (unsafe behavior), 10\% karena kondisi yang tidak aman (unsafe condition), dan 2\% tidak diketahui penyebabnya.

Peneliti melakukan studi pendahuluan yaitu dengan mengobservasi beberapa pekerja operator loading unloading minyak mentah dengan tujuan untuk dapat melihat dan mengetahui bagaimana perilaku aman pada pekerja di perusahaan tersebut. Dari hasil observasi studi pendahuluan di area produksi PT. X saat mengamati 10 orang pekerja, didapatkan 6 pekerja yang berperilaku aman, namun masih terdapat 4 pekerja yang berperilaku tidak aman. Perilaku tidak aman yang dapat diamati saat observasi diantaranya adalah kurangnya perhatian pekerja terhadap pemakaian APD, bekerja tidak sesuai SOP, kurangnya penerapan housekeeping, dan mengabaikan adanya rambu-rambu dan slogan K3 yang lainnya. Kegiatan kerja tersebut memiliki risiko bahaya yang dapat mencelakakan atau membahayakan pekerja, seperti bahaya kebakaran dan ledakan, ceceran dan tumpahan minyak, paparan uap benzene dan $\mathrm{H}_{2} \mathrm{~S}$, terpeleset, tersandung, dan terjatuh.

Perilaku tidak aman dapat terjadi karena rendahnya kesadaran pekerja terhadap K3 dan kurangnya kepedulian terhadap perilaku aman sebelum pekerja tersebut mengalami kecelakaan kerja. Secara umum, pekerja akan lebih cenderung memilih jalan pintas dan cara praktis dalam melakukan pekerjaannya, misalnya dengan sering bersikap acuh atau mengabaikan perilaku yang berbahaya dan mengutamakan agar pekerjaannya dapat cepat terselesaikan.

Perilaku kurang aman tersebut dapat meningkatkan risiko terjadinya kecelakaan kerja yang terjadi di tempat kerja. Salah satu upaya perusahaan dalam meningkatkan keselamatan dan kesehatan kerja adalah dengan menerapkan Behavior Based Safety (BBS). Penerapan BBS di perusahaan bertujuan untuk meningkatkan kesadaran pekerja, mitra kerja dan tamu mengenai aspek keselamatan kerja dengan melakukan pencatatan unsafe act, unsafe condition dan near miss. Diharapkan dengan penerapan BBS dapat meningkatkan safe behavior pekerja.

Upaya dalam perubahan perilaku pekerja dari perilaku tidak aman menjadi perilaku aman mulai dilakukan di Indonesia melalui penerapan Behavior Based Safety. Behavior Based Safety merupakan pendekatan yang digunakan perusahaan untuk mengubah perilaku unsafe dan berisiko pekerja menjadi perilaku yang aman (safe) sehingga keselamatan kerja di perusahaan tersebut juga meningkat. Penerapan Behavior Based Safety ini didasarkan bahwa sebagian besar kecelakaan kerja yang terjadi ialah dikarenakan perilaku yang tidak aman atau unsafe behavior, yaitu sebesar $85-90 \%$ (Anizar, 2012).

Penerapan BBS akan lebih efektif jika didukung dengan upaya peningkatan perilaku dengan Model Perilaku ABC. Model Perilaku ABC terdiri dari Activator, Behavior dan Consequence menjelaskan bahwa perilaku dipengaruhi langsung oleh activator yang mendahului terjadinya perilaku tertentu dan consequence yang memicu timbulnya perilaku tertentu atau perilaku baru yang diulang. Consequence juga dapat berperan sebagai activator baru yang dapat memicu munculnya perilaku baru. Perilaku aman dapat dilihat melalui observasi terhadap perilaku pekerja ketika melakukan pekerjaannya (Geller, 2001).

Tujuan dari penelitian ini adalah untuk menganalisis perilaku aman pada pekerja operator loading unloading minyak mentah. Perilaku aman pada penelitian ini meliputi penggunaan APD, penerapan housekeeping, dan kepatuhan terhadap SOP. Perilaku aman tersebut dapat terjadi karena adanya activator berupa pengetahuan, sikap, persepsi dan pelatihan K3. Perilaku aman tersebut dapat menimbulkan consequence berupa reward (pemberian hadiah) dan punishment (teguran dan pemotongan gaji). Penelitian ini akan dilakukan dengan menggunakan pendekatan perilaku melalui identifikasi faktor yang berperan sebagai activator dan consequence dalam perilaku (behavior) berdasarkan model ABC menurut Geller (2001) dan Cooper (2009). 


\section{METODE}

Penelitian ini dilakukan dengan melakukan pengamatan perilaku pekerja dan variabel yang ada dalam penelitian, sehingga penelitian ini termasuk dalam penelitian observasional. Penelitian dilakukan dalam kurun waktu tertentu pada praktik lapangan maka penelitian ini menggunakan rancang bangun cross-sectional study.

Penelitian ini dilakukan di operator loading unloading minyak mentah. Penelitian dimulai sejak pengumpulan data pada bulan Mei hingga pengolahan data Juni 2017. Populasi penelitian ini adalah seluruh pekerja operator loading unloading minyak mentah meliputi pekerja tetap maupun kontrak sebanyak 20 pekerja. Sampel dalam penelitian ini adalah seluruh pekerja operator loading unloading minyak mentah.

Variabel independen dalam penelitian ini adalah factor yang termasuk dalam activator (pengetahuan, sikap, persepsi, dan pelatihan K3) dan factor yang termasuk dalam consequence (reward dan punishment). Variabel dependen dalam penelitian ini adalah perilaku aman pekerja operator produksi. Penelitian ini menggunakan data primer dan data sekunder. Pengumpulan data primer dalam penelitian ini dilakukan melalui kuesioner dan observasi, sedangkan data sekunder berasal dari data perusahaan.

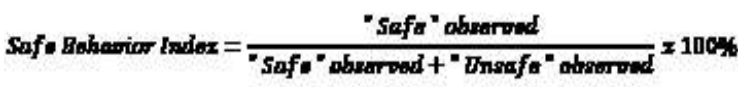

\section{Gambar 1. Rumus Safe Behaviour Index}

Total perilaku aman yang didapat melalui hasil observasi dihitung dengan menggunakan rumus Safe Behavior Index menurut Geller (2001) pada Gambar 1. Hasil Persentase dari rumus Safe behavior index sesuai Gambar 1, selanjutnya akan dikategorikan menjadi 3 kategori yaitu aman, cukup aman, dan kurang aman. Termasuk dalam kategori aman apabila persentase Safe Behavior Index $\geq 85 \%$, kategori cukup aman apabila persentase Safe Behavior Index 60-84.9\%; dan kategori kurang aman apabila persentase $\leq 59.9 \%$. Penentuan kategori tersebut tidak dijelaskan oleh Geller (2011), namun hanya ditunjukkan contoh perhitungan menggunakan rumus tersebut. Penggunaan kategori tersebut telah banyak digunakan pada penelitian sebelumnya.

Kuesioner yang digunakan bersifat tertutup dan menggunakan skala likert. Pada kuesioner pengetahuan menggunakan jawaban pilihan ganda. Hasil analisis kuesioner dan observasi akan ditampilkan atau digambarkan dalam tabel tabulasi silang dan dianalisis dengan penjelasan secara deskriptif. Hasil analisis kemudian dihubungkan dengan teori yang telah ada untuk diambil kesimpulan.

\section{HASIL}

\section{Gambaran Umum Perusahaan}

PT. X adalah perusahaan yang melakukan kegiatan usaha di sector hulu bidang minyak dan gas bumi yang meliputi eksplorasi dan eksploitasi. Kegiatan yang dilakukan PT. X tersebut hanya sebatas pengambilan minyak dan gas dari alam kemudian dilanjutkan dengan proses pengolahan minyak hingga mendapatkan minyak mentah yang sudah sesuai dengan standar (BSNW 0.2).

Perusahaan berkomitmen terhadap pelaksanaan program kebijakan Keselamatan dan Kesehatan Kerja Lindung Lingkungan (KLL). Kebijakan tersebut ditetapkan dan diturunkan dari pimpinan tertinggi pusat sampai dengan kebijakan dari pimpinan tingkat bawah.

Salah satu kebijakan perusahaan yaitu menerapkan sistem reward dan punishment untuk mendorong motivasi pekerja berpartisipasi dalam penerapan keselamatan kerja. Reward diberikan melalui lomba housekeeping, quiz PEKA, dan Key Performance Indicator berupa pemberian hadiah seperti jaket, safety shoes, dan lain-lain. Punishment diberikan kepada pekerja yang mengabaikan keselamatan kerja dalam bentuk teguran hingga pemotongan gaji. Departemen Health, Safety, Security and Environment (HSSE) secara berkala menyusun Basic Safety, pemeriksaan lingkungan kerja, pemeriksaan peralatan kerja, penanggulangan keadaan darurat, penyusunan SOP, pemantauan akses masuk perusahaan, Pelaksanaan audit internal, pengadaan APD dan alat keselamatan kerja, pengadaan rambu dan blower, dan pemantauan Penyakit Akibat Kerja (PAK).

Proses produksi secara singkat yaitu cairan fluida yang masih terdapat campuran berupa minyak, gas, dan air dari sumur pompa kemudian dialirkan ke area pengumpul produksi yang kemudian dikeringkan dengan menggunakan scrubber. Gas hasil pengeringan tersebut dimanfaatkan untuk bahan bakar, dan sisa gas dibakar di flare. Kegiatan produksi tersebut banyak terdapat potensi bahaya 
Tabel 1. Distribusi Pengetahuan Pekerja Operator Loading Unloading Minyak Mentah Tahun 2017

\begin{tabular}{lcc}
\hline \multicolumn{1}{c}{ Kategori } & Jumlah (n) & Persentase (\%) \\
\hline Baik & 7 & 35 \\
Cukup & 9 & 45 \\
Kurang & 4 & 20 \\
\hline Jumlah & 20 & 100 \\
\hline
\end{tabular}

Tabel 2. Distribusi Sikap Pekerja Operator Loading Unloading Minyak Mentah Tahun 2017

\begin{tabular}{lcc}
\hline \multicolumn{1}{c}{ Kategori } & Jumlah (n) & Persentase (\%) \\
\hline Baik & 4 & 20 \\
Cukup & 10 & 50 \\
Kurang & 6 & 30 \\
\hline Jumlah & 20 & 100 \\
\hline
\end{tabular}

yang dapat menyebabkan kecelakaan kerja namun masih terdapat beberapa pekerja yang kurang memperhatikan aspek K3 dalam bekerja.

\section{Distribusi Pengetahuan Pekerja}

Hasil distribusi pengetahuan pekerja terhadap Keselamatan Kerja dan Perilaku Aman ditampilkan dalam Tabel 1. Tabel 1 menunjukkan bahwa pengetahuan yang dimiliki oleh pekerja operator produksi tergolong baik dan cukup baik, namun masih terdapat kekurangan pada contoh perilaku aman dan tidak aman.

\section{Distribusi Sikap Pekerja}

Hasil distribusi sikap pekerja terhadap perilaku aman ditampilkan dalam Tabel 2. Tabel 2 menunjukkan bahwa sebagian besar sikap pekerja terhadap perilaku aman tergolong cukup baik. Pekerja menilai factor K3 harus diutamakan pada saat melakukan pekerjaan.

\section{Distribusi Persepsi Pekerja}

Hasil distribusi persepsi pekerja tentang bahaya dan risiko kecelakaan kerja ditampilkan dalam bentuk tabel. Tabel 3 menunjukkan bahwa persepsi pekerja sudah cukup baik terhadap bahaya dan risiko kecelakaan kerja.
Tabel 3. Distribusi Persepsi Pekerja Operator Loading Unloading Minyak Mentah Tahun 2017

\begin{tabular}{lcc}
\hline \multicolumn{1}{c}{ Kategori } & Jumlah (n) & Persentase (\%) \\
\hline Baik & 3 & 20 \\
Cukup & 11 & 50 \\
Kurang & 6 & 30 \\
\hline Jumlah & 20 & 100 \\
\hline
\end{tabular}

Tabel 4. Distribusi Pelatihan K3 Pekerja Operator Loading Unloading Minyak Mentah Tahun 2017

\begin{tabular}{lcc}
\hline \multicolumn{1}{c}{ Kategori } & Jumlah (n) & Persentase (\%) \\
\hline Baik & 7 & 35 \\
Cukup & 8 & 40 \\
Kurang & 5 & 25 \\
\hline Jumlah & 20 & 100 \\
\hline
\end{tabular}

\section{Distribusi Pelatihan K3}

Hasil distribusi pelatihan K3 pada pekerja operator produksi ditampilkan dalam bentuk tabel. Tabel 4 menunjukkan bahwa pelatihan K3 pada pekerja tergolong cukup baik. Pekerja menilai pelatihan K3 yang diberikan oleh perusahaan telah bermanfaat dalam membantu pekerjaan.

Tabel 5. Distribusi Reward Operator Loading Unloading Minyak Mentah Tahun 2017

\begin{tabular}{lcc}
\hline \multicolumn{1}{c}{ Kategori } & Jumlah (n) & Persentase (\%) \\
\hline Pernah & 7 & 35 \\
Tidak Pernah & 13 & 65 \\
\hline Jumlah & 20 & 100 \\
\hline
\end{tabular}

Tabel 6. Distribusi Punishment Operator Loading Unloading Minyak Mentah Tahun 2017

\begin{tabular}{lcc}
\hline \multicolumn{1}{c}{ Kategori } & Jumlah (n) & Persentase (\%) \\
\hline Pernah & 8 & 40 \\
Tidak Pernah & 12 & 60 \\
\hline Jumlah & 20 & 100 \\
\hline
\end{tabular}




\section{Distribusi Reward}

Hasil distribusi pekerja yang pernah mendapatkan dan tidak pernah mendapat reward. Tabel 5 dapat diketahui bahwa sebagian besar pekerja operator produksi yang tidak pernah mendapatkan reward sebanyak $65 \%$.

\section{Distribusi Punishment}

Hasil distribusi pekerja yang pernah mendapatkan dan tidak pernah mendapat punishment ditampilkan pada Tabel 6. Hasil pada Tabel 6 menunjukkan bahwa sebagian besar pekerja sebanyak $60 \%$ tidak pernah mendapat punishment.

\section{Distribusi Perilaku Aman}

Hasil distribusi perilaku aman Operator Loading Unloading Minyak Mentah Tahun 2017 ditampilkan pada Tabel 7. Hasil pada Tabel 7 dapat diketahui bahwa sebagian besar pekerja telah memiliki perilaku cukup aman dan aman. Sebanyak 5\% atau hanya satu orang pekerja dari hasil pengamatan yang memiliki perilaku kurang aman dalam melaksanakan pekerjaan.

Tabel 8 merupakan distribusi hasil observasi perilaku aman berdasarkan perilaku yang diamati

Tabel 7. Distribusi Perilaku Aman Pekerja Operator Loading Unloading Minyak Mentah Tahun 2017

\begin{tabular}{lcc}
\hline \multicolumn{1}{c}{ Kategori } & Jumlah (n) & Persentase (\%) \\
\hline Aman & 10 & 50 \\
Cukup & 9 & 45 \\
Kurang & 1 & 5 \\
\hline Jumlah & 20 & 100 \\
\hline
\end{tabular}

Tabel 8. Distribusi Hasil Observasi Perilaku Aman berdasarkan Perilaku yang diamati pada Operator Loading Unloading Minyak Mentah Tahun 2017

\begin{tabular}{lccc}
\hline Perilaku Aman & $\begin{array}{c}\text { Jumlah } \\
\text { Perilaku } \\
\text { Aman }\end{array}$ & $\begin{array}{c}\text { Jumlah } \\
\text { Perilaku } \\
\text { Berisiko }\end{array}$ & $\begin{array}{c}\text { Safe } \\
\text { Behavior } \\
\text { Index } \\
\text { (\%) }\end{array}$ \\
\hline Penggunaan APD & 41 & 10 & 80,39 \\
Housekeeping & 30 & 30 & 50 \\
Kepatuhan SOP & 117 & 23 & 83,57 \\
\hline Total & 228 & 63 & 78,35 \\
\hline
\end{tabular}

pada operator loading unloading minyak mentah. Hasil pada Tabel 8 dapat diketahui bahwa total rata-rata nilai Safe Behavior Index (SBI) yaitu $78,35 \%$ berada pada kategori cukup aman. Nilai SBI perilaku penggunaan APD sebesar 80,39\% dalam kategori cukup aman, pelaksanaan housekeeping sebesar $50 \%$ dalam kategori kurang aman, dan mengikuti SOP sebesar 83,57\% dalam kategori cukup aman.

Terdapat beberapa temuan at-risk behavior selama dilakukan observasi. At-risk behavior adalah perilaku yang dapat menimbulkan bahaya atau kecelakaan kerja. Salah satu bentuk at-risk behavior yang dilakukan adalah perilaku penggunaan Alat Pelindung Diri dengan benar masih belum dilakukan, masih terdapat safety helmet pekerja yang tidak terdapat chain stripe (tali dagu) dan tidak memakai respirator saat bekerja. Terkait dengan pelaksanaan housekeeping masih terdapat ceceran minyak dan sampah di area kerja.

\section{Distribusi Silang Activator dengan Perilaku Aman}

Activator yang baik akan menyebabkan terjadinya perilaku aman. Faktor yang berperan menjadi activator meliputi pengetahuan, sikap, dan pelatihan K3. Hasil distribusi silang perilaku aman pekerja dengan faktor yang berperan sebagai

Tabel 9. Distribusi Perilaku Aman Pekerja Operator Loading Unloading Minyak Mentah dengan Activator Tahun 2017

\begin{tabular}{ccccccccc}
\hline & \multicolumn{8}{c}{ Safe Behavior } \\
\cline { 2 - 9 } Activator & Aman & \multicolumn{1}{c}{ Cukup } & \multicolumn{1}{c}{ Kurang } & \multicolumn{2}{c}{ Total } \\
\cline { 2 - 9 } & n & \% & n & $\%$ & n & $\%$ & N & $\%$ \\
\hline Pengetahuan & & & & & & & \\
Baik & 6 & 85,7 & 1 & 14,3 & 0 & 0 & 7 & 100 \\
Cukup & 3 & 33,3 & 6 & 66,7 & 0 & 0 & 9 & 100 \\
Kurang & 0 & 0 & 3 & 75,0 & 1 & 25 & 4 & 100 \\
\hline Sikap & & & & & & & & \\
Baik & 4 & 100 & 0 & 0 & 0 & 0 & 4 & 100 \\
Cukup & 5 & 50 & 5 & 50 & 0 & 0 & 10 & 100 \\
Kurang & 0 & 0 & 5 & 50 & 1 & 0 & 6 & 100 \\
\hline Pelatihan K3 & & & & & & & \\
Baik & 3 & 42,9 & 3 & 42,9 & 1 & 14,3 & 7 & 100 \\
Cukup & 5 & 62,5 & 3 & 37,5 & 0 & 0 & 8 & 100 \\
Kurang & 1 & 20 & 4 & 80 & 0 & 0 & 5 & 100 \\
\hline
\end{tabular}


activator pada pekerja operator loading unloading minyak mentah ditampilkan dalam Tabel 9.

Hasil pada Tabel 9 dapat diketahui bahwa sebagian besar pekerja yang memiliki pengetahuan baik sebesar $85,7 \%$ atau 6 orang pekerja telah berperilaku aman. Pekerja yang memiliki sikap baik telah berperilaku aman sebanyak $100 \%$ atau 4 orang pekerja. Pekerja yang mempunyai persepsi cukup baik dengan perilaku aman sebesar $62.5 \%$ atau 5 orang pekerja.

\section{Distribusi Silang Consequence dengan Perilaku Aman}

Consequence dapat mendukung terjadinya perilaku aman yang akan dilakukan kembali oleh

Tabel 10. Distribusi Perilaku Aman Pekerja Operator Loading Unloading Minyak Mentah dengan Concequence Tahun 2017

\begin{tabular}{lccccccccc}
\hline & \multicolumn{8}{c}{ Safe Behavior } \\
\cline { 2 - 9 } Consequence & \multicolumn{1}{c}{ Baik } & \multicolumn{1}{c}{ Cukup } & \multicolumn{1}{c}{ Kurang } & \multicolumn{2}{c}{ Total } \\
\cline { 2 - 9 } & $\mathbf{n}$ & $\%$ & $\mathbf{n}$ & $\%$ & $\mathbf{n}$ & $\%$ & $\mathbf{N}$ & $\%$ \\
\hline Reward & & & & & & & & \\
Pernah & 5 & 71,4 & 2 & 28,6 & 0 & 0 & 7 & 100 \\
Tidak pernah & 4 & 30,8 & 8 & 61,5 & 1 & 7,7 & 13 & 100 \\
\hline Punishment & & & & & & & & \\
Pernah & 3 & 37,5 & 4 & 50,0 & 1 & 12,5 & 8 & 100 \\
Tidak pernah & 6 & 50,0 & 6 & 50,0 & 0 & 0 & 12 & 100 \\
\hline
\end{tabular}

para pekerja yang sudah pernah berperilaku aman dan akan menjadi pendukung untuk melakukan perilaku aman bagi pekerja yang sebelumnya masih berperilaku tidak aman. Hasil distribusi perilaku aman pekerja dengan variabel reward dan punishment dalam penelitian ditampilkan dalam Tabel 10.

Hasil pada Tabel 10 dapat diketahui bahwa sebagian besar pekerja yang pernah mendapatkan reward sebesar $71,4 \%$. Reward yang dimaksud dalam penelitian meliputi pujian dan promosi kerja telah berperilaku aman. Sebesar $61,5 \%$ pekerja yang menyatakan tidak pernah mendapatkan reward telah berperilaku cukup aman. 50\% pekerja yang pernah mendapatkan hukuman di perusahaan telah berperilaku cukup aman. $50 \%$ pekerja lain sebagian besar pekerja yang tidak pernah mendapatkan hukuman selama bekerja di perusahaan tersebut telah berperilaku cukup aman.

\section{PEMBAHASAN}

Hasil observasi perilaku aman pekerja telah diketahui sudah cukup aman, namun perilaku housekeeping masih kurang aman. Hal tersebut dapat disebabkan oleh activator dan consequence sesuai dengan model perilaku ABC.

Setiap perilaku yang dilakukan oleh seseorang sebelum perilaku tersebut terjadi didasari oleh adanya activator yang mendasari setiap perilaku yang dilakukan seseorang sebelum perilaku tersebut terjadi. Factor adanya activator dapat menyebabkan terjadinya perilaku namun juga bias menyebabkan perilaku tersebut tidak terjadi (Cooper, 2001).

Faktor yang berperan sebagai activator pada Pekerja Operator Loading Unloading Minyak Mentah meliputi pengetahuan mengenai keselamatan kerja dan perilaku tidak aman dalam bekerja, sikap terhadap perilaku aman, dan pelatihan K3. Pengetahuan merupakan hasil tahu seseorang terhadap objek yang diamati melalui proses pengindraan. Pengetahuan berpengaruh terhadap pola pikir dan perilaku seseorang. Pekerja diberikan pertanyaan mengenai pengetahuan yang dimiliki mengenai keselamatan kerja dan contoh perilaku aman dan perilaku tidak aman. Pekerja berpengetahuan baik jika mampu menjawab dengan benar mengenai kecelakaan kerja dan contoh perilaku aman dan tidak aman. Hampir seluruh pekerja menjawab dengan benar pertanyaan mengenai keselamatan kerja. Masih terdapat beberapa pekerja yang tidak bias mengategorikan perilaku yang termasuk aman dan tidak aman.

Ramli (2013) menyatakan bahwa manajemen perusahaan dapat melakukan upaya pendekatan Sumber Daya Manusia (SDM) melalui pembinaan dan pelatihan, promosi $\mathrm{K} 3$, dan komunikasi K3. Menurut Notoatmodjo (2007), Strategi peningkatan pengetahuan agar perilaku aman pekerja meningkat perlu waktu yang lama, namun perilaku yang dihasilkan akan bersifat permanen.

Perusahaan sudah melakukan pelatihan terkait K3, namun tidak secara berkala. Komunikasi K3 sudah dilakukan oleh perusahaan melalui adanya program safety meeting, safety briefing dan management walk trough.

Pekerja dengan tingkat pengetahuan baik dan cukup baik telah melakukan perilaku aman. Hal ini disebabkan karena setiap perilaku dapat dipengaruhi dan didasari oleh banyak faktor, tidak hanya pengetahuan. Pengetahuan yang kurang, menyebabkan pekerja tidak tahu akan perilaku 
aman dan perilaku tidak aman. Terdapat faktor lain yang menyebabkan meskipun pekerja tingkat pengetahuannya kurang namun berperilaku aman yaitu faktor eksternal dari lingkungan melalui adanya safety patrol dari personel HSSE yang melakukan patrol atau pengawasan terhadap pekerja saat di lapangan produksi untuk mengingatkan pekerja yang melakukan tindakan tidak aman.

Notoatmodjo (2007) menyatakan bahwa sikap merupakan penilaian sesorang mengenai objek tertentu. Setelah objek tersebut diketahui, proses selanjutnya yaitu penilaian terhadap objek tersebut. Penilaian terhadap objek merupakan proses adopsi perilaku tahap kedua.

Ramli (2013) menyatakan bahwa kemauan pekerja yang rendah dalam berperilaku aman merupakan salah satu penyebab terjadinya perilaku tidak aman. Meskipun pekerja mengetahui dan mampu melaksanakan pekerjaan secara aman, jika dalam dirinya tidak terdapat kemauan dan kepedulian terhadap perilaku aman maka terjadilah kecelakaan.

Hasil pengukuran menggunakan kuesioner diketahui bahwa pekerja operator loading unloading minyak mentah telah memiliki sikap yang cukup baik terhadap perilaku aman. Mereka memprioritaskan serta setuju terhadap penerapan perilaku aman dalam bekerja dan tidak setuju terhadap perilaku tidak aman saat bekerja. Pekerja dapat menilai perilaku untuk menentukan aman dan tidak aman untuk dilakukan yang membahayakan keselamatan.

Pekerja operator produksi telah menilai bahwa perilaku aman dan faktor Keselamatan dan Kesehatan Kerja (K3) merupakan hal yang penting dilaksanakan untuk mencegah terjadinya kecelakaan kerja atau hal lain yang dapat membahayakan keselamatan pekerja. Pekerja operator produksi yang mempunyai sikap baik telah melakukan perilaku aman, pekerja yang memiliki sikap kurang juga melakukan perilaku aman. Perilaku tersebut disebabkan oleh faktor lingkungan yaitu sikap antar pekerja yang saling mengingatkan jika ada rekan yang berperilaku tidak aman, namun sikap saling mengingatkan tersebut hanya dilakukan saat ada pengawas datang.

Ramli (2013), menyatakan bahwa pelatihan merupakan salah satu usaha untuk meningkatkan Knowledge, Skill, dan Attitude (KSA) sehingga pelatihan harus dirancang sesuai dan spesifik dengan kebutuhan pekerja. Pelatihan merupakan salah satu cara dalam pendekatan manusia yang bertujuan untuk mencegah terjadinya kecelakaan kerja. Health and Safety Executive (2000) menyatakan bahwa pelatihan adalah hal yang penting untuk diberikan sebagai upaya pemicu perilaku aman pekerja.

Hasil pengukuran melalui kuesioner menjelaskan bahwa hampir seluruh pekerja operator produksi menyatakan bahwa pelatihan atau training yang diberikan telah sesuai dengan pekerjaan yang mereka lakukan. Pekerja juga mendapat training tentang K3 dan Basic Safety Training (BST). Setiap pekerja yang telah mendapat training apapun akan tercantum pada HSE passport mereka yang berisi riwayat kesehatan, pelatihan, dan lain-lain. Responden dalam penelitian merasa pelatihan yang mereka terima bermanfaat dalam pelaksanaan tugas dan memberikan kontribusi agar mereka berperilaku aman, seperti membantu mereka memahami penggunaan APD yang benar, bekerja sesuai Standar Operasional Prosedur (SOP) dan keselamatan. Hal ini menunjukkan bahwa ada penambahan atau peningkatan Knowledge, Skill, dan Attitude (KSA) dari adanya pelatihan yang diberikan dan hal ini sesuai dengan tujuan dari diadakannya pelatihan (Ramli, 2013)

Manajemen perusahaan juga menyetujui bahwa selain pelatihan $\mathrm{K} 3$, pekerja juga mendapat pelatihan sesuai dengan pekerjaan dan kebutuhannya. Namun pelatihan ini tidak dilaksanakan berkala dan hanya dilakukan bila dirasa diperlukan seperti saat setelah terjadinya insiden. As'ad (1998) menyatakan bahwa pelatihan perlu dilaksanakan kembali sebagai bentuk penyegaran bagi pekerja.

Consequence adalah hasil (outcome) dari perilaku seseorang yang dapat mengubah kemungkinan apa yang akan terjadi di kemudian hari dan dapat kemungkinan mempengaruhi perilaku yang sama akan terulang kembali. Health and Safety Executive (2002) menyatakan bahwa reward dan punishment merupakan suatu bentuk konsekuensi atau akibat yang diterima pekerja akibat perilaku mereka. Reward merupakan bentuk penguatan positif dan punishment atau hukuman identik dengan menerima sesuatu yang tidak kita inginkan atau kehilangan sesuatu yang kita miliki atau kita inginkan.

Hasil pada Tabel 10 dapat diketahui bahwa sebagian besar pekerja yang pernah mendapatkan reward telah melakukan perilaku aman sedangkan pekerja yang menyatakan tidak pernah mendapatkan reward telah berperilaku cukup aman. Pekerja yang pernah mendapatkan hukuman di perusahaan tersebut telah berperilaku cukup aman, sedangkan pekerja yang tidak pernah mendapatkan hukuman 
selama bekerja di perusahaan tersebut juga telah berperilaku aman.

Reward yang diberikan oleh perusahaan kepada pekerja dapat mendukung dan menjadi pendorong untuk melakukan perilaku aman dalam bekerja. Contoh reward yang diberikan oleh perusahaan adalah pimpinan memberikan pujian dan penghargaan kepada pekerja yang berperilaku aman, bahkan pemberian kenaikan pangkat. Reward yang diberikan tersebut dapat memberi semangat pekerja untuk mau dan mampu melakukan pekerjaan sesuai dengan SOP yang berlaku. Perilaku baru atau perubahan perilaku menjadi yang lebih baik dan aman yang dilakukan oleh pekerja juga dapat didasari atau dipicu dari adanya consequence berupa reward dan punishment yang telah didapatkan sebelumnya. Adanya pemberian hukuman kepada pekerja yang melanggar peraturan dan berperilaku tidak aman dapat menjadi sesuatu yang ditakuti dan dihindari, contoh dari punishment yang dapat diberikan oleh perusahaan adalah pemberian teguran dari manajemen atau pimpinan, berupa sanksi atau teguran dan pemotongan gaji kepada pekerja yang berperilaku tidak aman.

Terdapat sistem penghargaan dan hukuman pada perusahaan. Penghargaan diberikan kepada pekerja yang melakukan observasi perilaku terbanyak selama setahun dan kepada pekerja yang memberikan komentar terbaik dalam kartu observasi. Penghargaan yang diberikan dapat berupa barang yang meliputi tas, jaket, dan peningkatan gaji untuk pekerja yang memiliki peningkatan kinerja. Bentuk penghargaan lain dapat berupa pujian apabila dijumpai pekerja yang melakukan perilaku aman ketika bekerja. Hukuman diberikan bagi pekerja yang tidak melakukan observasi sama sekali dan pekerja yang melakukan kesalahan sehingga menyebabkan kerugian bagi perusahaan. Hukuman yang diberikan dapat berupa tidak ada kenaikan gaji dan skorsing. Menurut manajemen pemberian penghargaan dan hukuman ini memotivasi pekerja untuk berperilaku aman dan manajemen merasa belum ada hambatan dalam pelaksanaan sistem ini.

Teori Geller (2001) menyebutkan bahwa activator dapat menjadi pemicu munculnya suatu perilaku dan akan menimbulkan adanya consequence dari perilaku tersebut. Jika seseorang berperilaku aman maka akan mendapatkan konsekuensi yang baik dan bermanfaat, namun jika berperilaku tidak aman maka akan mendapatkan sanksi atau hukuman sebagai konsekuensi atas kesalahan atau pelanggaran yang telah dilakukan.

Perilaku merupakan faktor penting penyebab terjadinya kecelakaan kerja. Lawrence Green Theory menyebutkan bahwa terdapat dua faktor yang mempengaruhi perilaku manusia yaitu faktor perilaku dan faktor di luar perilaku. Perilaku aman pekerja di tempat kerja meliputi tindakan pengoperasian peralatan yang benar, mampu saling memperingatkan pekerja lain yang bekerja tidak aman, penggunaan Alat Pelindung Diri yang benar sesuai potensi bahaya dan peraturan perusahaan, mengangkat material dengan beban yang sesuai dan menempatkannya pada tempat yang seharusnya, mengambil benda atau material dengan posisi tubuh yang ergonomis, disiplin, dan lain sebagainya.

\section{Alat Pelindung Diri (APD)}

Hasil penilaian sikap dan persepsi pekerja menggunakan kuesioner. Hasil rekapitulasi kuesioner dalam penelitian menyebutkan bahwa sebagian besar pekerja merasa telah berperilaku aman ketika melakukan pekerjaan. Berbeda dengan hasil observasi dalam penelitian yang menunjukkan bahwa pekerja masih belum sepenuhnya memperhatikan penggunaan APD terutama penggunaan respirator. Terdapat pekerja yang ditemui tidak menggunakan respirator pada saat melakukan pekerjaan meskipun dalam area kerja terdapat bahaya gas benzene. Pekerja yang tidak memakai respirator saat melakukan pekerjaan masih tergolong banyak, karena mereka menilai bahwa adanya blower pada area kerja sudah dapat mengatasi adanya paparan gas benzene. Tempat kerja berada di area terbuka (luar ruang) sehingga sangat memungkinkan adanya peningkatan kadar uap benzene ketika arah angin berlawanan dengan arah angin blower maka mengingat area kerja berada di luar ruangan.

Sebanyak 34\% pekerja sudah baik terkait dengan aspek kelayakan dan cara merawat APD, namun sebagian pekerja masih memakai APD yang tidak layak seperti chainstripe helm yang sudah kotor dan tidak elastic dan sarung tangan yang kotor. Para pekerja tetap menggunakan APD yang sudah tidak standar tersebut hingga mendapatkan APD yang baru dari fungsi HSSE. Persediaan APD pada fungsi HSSE telah habis sehingga harus menunggu hingga persediaan APD tercukupi kembali. 


\section{Housekeeping atau Ringkas, Rapi, Resik, Rawat dan Rajin (5R)}

Pelaksanaan housekeeping yang harus dilakukan oleh pekerja operator produksi yaitu bekerja dengan hati-hati agar tidak ada tumpahan atau ceceran minyak yang jatuh sehingga dapat menimbulkan bahaya kebakaran. Hal lain yang harus dilakukan adalah menyingkirkan barang yang tidak berguna pada area kerja seperti sampah, alat kebersihan, dan lain-lain. Pekerja wajib membersihkan alat kerja setelah digunakan seperti tongkat ukur minyak yang setelah dimasukkan dalam minyak. Pekerja juga wajib merapikan pada area kerja saat pekerjaan telah selesai seperti mematikan pompa, menutup valve, dan mengembalikan alat kerja pada tempatnya.

Hasil pengukuran persepsi dan sikap melalui kuesioner menjelaskan bahwa pekerja merasa telah melakukan housekeeping dengan baik, namun dari hasil observasi yang dilakukan diperoleh hasil bahwa semua pekerja belum melakukan housekeeping dengan baik. Hal tersebut dapat terjadi karena perbedaan persepsi antara housekeeping yang pekerja pahami dengan observer. Pekerja memahami bahwa housekeeping adalah merapikan dan membersihkan area kerja saat pekerjaan selesai dan saat pekerja meninggalkan area kerja. Tindakan menyingkirkan barang yang tidak berguna dan membersihkan ceceran minyak dari area kerja juga dilakukan saat pekerja akan pulang. Tindakan tersebut dilakukan saat pekerja sedang melakukan pekerjaan karena dapat mengganggu pekerjaan dan memungkinkan sebagai sumber untuk terjadinya kecelakaan kerja.

\section{Standard Operating Procedur (SOP)}

Standar Operating Procedure (SOP) merupakan panduan yang digunakan pekerja dalam melakukan pekerjaan. SOP telah disusun dengan sedemikian rupa melalui berbagai pertimbangan keselamatan kerja untuk menurunkan risiko kecelakaan kerja. Berdasarkan hasil pengukuran sikap pada kuesioner yang di isi pekerja menganggap telah membaca SOP sebelum memulai pekerjaan, namun file SOP yang seharusnya terdapat di area kerja tidak ditemukan karena sudah hilang pada saat terjadi perbaikan. Ketidaktersediaan SOP di area kerja tersebut tidak mengurangi kelancaran pekerjaan karena mayoritas pekerja sudah bekerja antara 11 hingga 20 tahun, sehingga keahlian dalam melakukan pekerjaan sudah terlatih dan terbiasa.

Hasil observasi yang dilakukan pada saat penelitian menunjukkan bahwa pelaksanaan SOP pekerjaan sudah baik, namun masih terdapat beberapa langkah prosedur yang tidak dilakukan seperti memasang kabel grounding. Fungsi dari kabel grounding itu adalah sebagai penghantar arus saat terjadi transfer minyak. Arus petir biasanya dapat menyambar, saat pekerjaan dilakukan siang hari maka tidak ada petir sehingga sebagian pekerja menganggap pemasangan kabel grounding tidak perlu dilakukan. Pekerja operator produksi tidak melakukan pengecekan terhadap APD personil lain saat akan melakukan pekerjaan. Pekerja operator produksi terkadang tidak melakukan pekerjaan sesuai SOP sendiri namun meminta pekerja lain untuk melakukan seperti mengukur cairan minyak dalam tangki, membuka valve, dan lainnya.

Hasil analisis yang telah dilakukan sesuai dengan model perilaku ABC yang menjelaskan bahwa adanya faktor yang berperan sebagai activator dan consequence. Faktor yang berperan sebagai activator dapat menjadi penyebab atau pemicu munculnya suatu perilaku dan akan memicu timbul adanya pemberian faktor yang berperan sebagai consequence yang akan didapatkan sebagai outcome atau output dari perilaku aman yang telah dilakukan tersebut.

Reward akan diperoleh jika seseorang tersebut berperilaku aman. Punishment akan diperoleh seseorang sebagai akibat dari kesalahan atau pelanggaran yang dilakukan.

\section{SIMPULAN}

Hasil penelitian serta analisis dalam penelitian menunjukkan bahwa perilaku aman pekerja operator loading unloading minyak mentah berupa penggunaan APD, pelaksanaan housekeeping dan bekerja sesuai dengan SOP. Perilaku aman pada pekerja dipicu oleh peran pengetahuan pekerja yang baik terhadap keselamatan kerja dan perilaku aman melalui upaya komunikasi K3 yang dilakukan secara berkala oleh perusahaan.

Sikap pekerja juga berperan penting dalam terjadinya perilaku aman. Hasil pengukuran yang dilakukan menunjukkan hasil bahwa pekerja mempunyai sikap yang cukup baik terhadap perilaku aman. Hal tersebut ditunjukkan dengan adanya sikap saling mengingatkan antar rekan kerja agar memakai APD yang terlihat saat observasi dilakukan. Pelatihan K3 yang pernah diperoleh pekerja juga memiliki peran penting dalam meningkatkan pengetahuan pekerja terhadap pekerjaan dan mengenai aspek K3. 
Perilaku aman pada pekerja operator produksi loading unloading yang memiliki nilai tertinggi adalah penggunaan kelengkapan APD yang layak dan perawatan APD serta bekerja dengan mengikuti SOP yang ada. Perilaku housekeeping pada responden penelitian dirasa masih kurang. Hal ini dapat disebabkan oleh rendahnya kemauan pekerja dan kurangnya pengetahuan mengenai cara melakukan housekeeping dan bahaya yang ditimbulkan.

Consequence yang memiliki nilai tertinggi pada pekerja operator produksi loading unloading yaitu punishment yang tidak pernah didapatkan selama bekerja. Kurangnya penerapan reward dan consequences secara konsisten sebagai motivasi perilaku aman pekerja juga memiliki peran penting dalam terjadinya perilaku aman pekerja.

\section{DAFTAR PUSTAKA}

Anizar., 2012. Teknik Keselamatan dan Kesehatan Kerja di Industri. Yogyakarta: Graha Ilmu.

As'ad, M., 1998. Psikologi Industri. Yogyakarta: Liberty Yogyakarta.

Badan Penyelenggara Jaminan Sosial Ketenagakerjaan. Angka Kecelakaan Kerja. Tersedia di http://www.
bpjsketenagakerjaan.go.id/berita/2943/AngkaKasus-Kecelakaan-Kerja-Menurun.html. [sitasi 15 July 2017].

Cooper, D., 2009. Behavioral Safety A Framework For Success. USA: B-Safe Management Solution, Inc.

Geller, S.E., 2001. The Psychology 07 Safety Handbook. Boca Raton. Lewis Publisher.

Geller, E.S., 2001. Working Safe: How to Help People Actively Care for Health and Safety. $2^{\text {nd }}$ Edition. USA: CRC Press LLC.

Health and Safety Executive., 2000. Safety Climate Assessment Tool Guide.

Kementerian Tenaga Kerja dan Transmigrasi Republik Indonesia., 2017. Kematian Akibat Kecelakaan Kerja. Tersedia di http://www. harnas.co/2017/03/01/kemenaker-kematianakibat-kecelakaan-kerja-tinggi- [sitasi pada 15 Juli 2017]

Notoatmodjo, S., 2007. Promosi Kesehatan \& Ilmu Perilaku. Jakarta: Rineka Cipta.

Ramli, S., 2013. Sistem Manajemen Keselamatan dan Kesehatan Kerja OHSAS 18001. Jakarta: Dian Rakyat. 